\title{
Effect of Quenching Process on Microstructure and performance of High-Boron High-Speed Steel
}

\author{
Fu Han-guang ${ }^{1}$, Yang Yong-wei ${ }^{2}$
} Cheng Xiao-le ${ }^{1}$, Qu Yin-hu ${ }^{1}$

\begin{abstract}
${ }^{1}$ School of Mechanical and Electrical Engineering, Xi'an Polytechnic University, 710048, Xi'an, Shaanxi, China.
${ }^{2}$ School of Materials Science and Engineering, Beijing University of Technology, 100124, Beijing, Beijing, China. e-mail: fhg64@263.net, 40265584@qq.com, xiaole.cheng@qq.com, quyinhu@ sina.com
\end{abstract}

\begin{abstract}
The effects of quenching process on microstructure and hardness of High-Boron High-Speed Steel (HB-HSS) containing $0.4 \% \mathrm{C}-6.0 \% \mathrm{Cr}-4.0 \% \mathrm{Mo}-1.0 \% \mathrm{~V}-1.0 \% \mathrm{Si}-0.5 \mathrm{Mn}-\mathrm{x} \% \mathrm{~B}-\mathrm{y} \% \mathrm{Al}(\mathrm{x}=1.0,1.5,2.0, \mathrm{y}=1.0,2.0,3.0)$ were investigated by means of optical microscopy (OM), scanning electron microscopy (SEM), X-ray diffraction (XRD), and Rockwell hardness tester. The experimental results indicate that the quenching microstructure of HB-HSS consists of $\alpha-\mathrm{Fe}, \mathrm{M}_{2}(\mathrm{~B}, \mathrm{C}), \mathrm{M}_{7}(\mathrm{~B}, \mathrm{C})_{3}$ and a few of $\mathrm{M}_{23}(\mathrm{C}, \mathrm{B})_{60}$ With the increase of quenching temperature, the net structure of borocarbides is damaged and the borocarbides are evenly distributed in the matrix. When the quenching temperature is $1050{ }^{\circ} \mathrm{C}$, the Rockwell hardness of HB-HSS increases with the increase of boron content. The Rockwell hardness of HB-HSS decreases with the increase of aluminum content. When the quenching temperature is $1050{ }^{\circ} \mathrm{C}$, the aluminum content is $1.0 \%$ and boron content is $1.0 \%-2.0 \%$, the combination of the microstructure and the hardness of HB-HSS is the best.
\end{abstract}

Keywords: High-boron high-speed steel; Quenching microstructure; Borocarbide; Hardness.

\section{INTRODUCTION}

Recently, high-speed steel rolls have been used for hot mill work rolls by increasing their carbon and vanadium contents, and were found suitable as replacement for high chromium white cast iron and high Ni$\mathrm{Cr}$ infinite chill iron rolls [1,2]. However, high-speed steel rolls contain many cost alloy elements, such as tungsten, molybdenum, vanadium, niobium, cobalt, etc., which incurs higher production cost and restricts the application of high-speed steel rolls [3]. In recent years, high boron wear-resistant alloy has been widely concerned in the world [4-6]. High boron wear-resistant materials have been extensively and deeply studied, and breakthroughs have been made in the application of high boron wear-resistant steel in the manufacture of new generation of wear-resistant materials [7,8]. The borocarbide has high hardness and good thermal stability. In the traditional high speed steel, adding boron to replace some tungsten and molybdenum elements and adding a small amount of vanadium elements to form new High-Boron High-Speed Steel (HBHSS) is a major research direction at present [9]. Through changing the content of boron and carbon to control the volume fraction and distribution of borocarbides in matrix, HB-HSS has been developed that can be used as excellent wear-resistant roll material $[10,11]$. The production cost of HB-HSS roll is lower than that of high-speed steel roll. Aluminium as an alloying element has long been used in high-speed steel, replacing parts of tungsten, molybdenum elements to improve the red hardness of steel $[12,13]$. It can improve the tempering stability, hardness and red hardness of high-speed steel for it mainly solubilses in the matrix [14-16]. In order to improve the wear resistance in high temperature, the appropriate amount of aluminum is added to the high-speed steel.

The $\mathrm{M}_{2}(\mathrm{~B}, \mathrm{C})$ hard phase exists in the matrix as network. It can enhance the wear resistance, but also greatly increases the brittleness of the HB-HSS material [17]. In view of the above shortcoming, through proper design of heat treatment process, the network eutectic borocarbides were broken and dispersed in the matrix, which can improve the comprehensive properties of HB-HSS materials. In this work, the ThermoCalc software was used to calculate equilibrium phase with different boron concentration [18]. On the basis of the calculation of phase diagram, this paper selects different boron and aluminum content, combined with different temperature quenching process, to study the change trend of $\mathrm{M}_{2}(\mathrm{~B}, \mathrm{C})$ morphology and quantity in the microstructure. The research results will provide reference for the selection of the optimum composition 
and the heat treatment process of HB-HSS.

\section{MATERIALS AND METHODS}

\subsection{The preparation of specimens}

The boron content of HB-HSS was chosen as $1.0 \%, 2.0 \%$ and $3.0 \%$ respectively. When the boron content was $2.0 \%$, the aluminium content was chosen as $1.0 \%, 1.5 \%, 2.0 \%$, respectively. The design composition of HB-HSS is shown in Table 1. HB-HSS were melted in a medium frequency induction furnace and poured into metal mold. The pouring temperature is $1773 \mathrm{~K}$ and the mold was preheated to $573 \mathrm{~K}$ before pouring. The ingot is a cylinder with $100 \mathrm{~mm}$ diameter and $300 \mathrm{~mm}$ length. The specimens were prepared from the center of ingots by wire cutting with the size $15 \mathrm{~mm} \times 15 \mathrm{~mm} \times 15 \mathrm{~mm}$. The chemical composition of HB-HSS was determined by x-ray fluorescence spectrum analysis (XRF), and the test results are shown in Table 2. Due to the effective element of the test range of $11(\mathrm{Na})$ to 92 element (U), XRF analysis did not test the content of carbon and boron elements, and the rest of the alloy elements are close to the design value. In order to accurately test the content of boron and carbon in the cast samples, the analytical method was used to determine the content of elements in the samples. The compositions of boron and carbon elements testing by chemical analysis are shown in Table 3. From the test results we can know that the absorptivity rate of boron element is more than $85 \%$, and the carbon element is in the range of $0.35-0.42$ wt. $\%$.

Table 1: The design composition of the alloy (mass fraction, \%).

\begin{tabular}{cccccccccc}
\hline SAMPLE & C & Cr & Al & Mo & V & Mn & Si & B & Fe \\
\hline $1 \#$ & 0.4 & 6.0 & 1.0 & 4.0 & 1.0 & 0.5 & 1.0 & 1.0 & Bal \\
$2 \#$ & 0.4 & 6.0 & 1.0 & 4.0 & 1.0 & 0.5 & 1.0 & 2.0 & Bal. \\
$3 \#$ & 0.4 & 6.0 & 1.0 & 4.0 & 1.0 & 0.5 & 1.0 & 3.0 & Bal. \\
$4 \#$ & 0.4 & 6.0 & 1.5 & 4.0 & 1.0 & 0.5 & 1.0 & 2.0 & Bal. \\
$5 \#$ & 0.4 & 6.0 & 2.0 & 4.0 & 1.0 & 0.5 & 1.0 & 2.0 & Bal. \\
\hline
\end{tabular}

Table 2: XRF results of the alloy (mass fraction, \%).

\begin{tabular}{cccccccc}
\hline SAMPLE & Cr & Al & Mo & V & Mn & Si & Fe \\
\hline $1 \#$ & 5.80 & 0.76 & 5.77 & 0.82 & 0.56 & 1.18 & Bal. \\
$2 \#$ & 5.78 & 0.80 & 5.72 & 1.06 & 0.56 & 1.24 & Bal. \\
$3 \#$ & 6.20 & 0.68 & 5.87 & 0.91 & 0.65 & 1.08 & Bal. \\
$4 \#$ & 7.36 & 1.24 & 5.35 & 0.82 & 0.53 & 1.07 & Bal. \\
$5 \#$ & 7.56 & 2.08 & 5.56 & 0.77 & 0.68 & 1.15 & Bal. \\
\hline
\end{tabular}

Table 3: The composition of $\mathrm{B}, \mathrm{C}$ by chemical analysis (mass fraction, $\%$ ).

\begin{tabular}{ccccc}
\hline SAMPLE & $\begin{array}{c}\text { C CONTENT } \\
\text { (WT.\%) }\end{array}$ & $\begin{array}{c}\text { B CONTENT } \\
\text { (WT.\%) }\end{array}$ & $\begin{array}{c}\text { DESIGNED B } \\
\text { CONTENT } \\
\text { (WT.\%) }\end{array}$ & $\begin{array}{c}\text { ABSORPTIVITY RATE } \\
\text { OF B } \\
(\%)\end{array}$ \\
\hline $1 \#$ & 0.42 & 0.85 & 1.0 & 85.0 \\
$2 \#$ & 0.38 & 1.82 & 2.0 & 91.0 \\
$3 \#$ & 0.35 & 2.75 & 3.0 & 91.6 \\
$4 \#$ & 0.38 & 1.78 & 2.0 & 89.0 \\
$5 \#$ & 0.40 & 1.84 & 2.0 & 92.0 \\
\hline
\end{tabular}




\subsection{Quenching process}

\subsubsection{Calculation of phase diagram}

The equilibrium solidification process was calculated with the content of the following elements: $1.0 \% \mathrm{Al}$ 、 $0.4 \% \mathrm{C} 、 6.0 \% \mathrm{Cr} 、 4.0 \% \mathrm{Mo} 、 1.0 \% \mathrm{Si} 、 0.5 \% \mathrm{Mn}$ and $1.0 \% \mathrm{~V}$, boron content is $1.0 \% \sim 3.0 \%$. The TCFE database, POLY-3 module and POST module were used under the condition $\mathrm{T}=1200 \mathrm{~K}, \mathrm{P}=105 \mathrm{kPa}$. The equilibrium criterion was the minimum of Gibbs free energy [19-22]. In the calculation process, the starting temperature is $1750{ }^{\circ} \mathrm{C}$ and cooled to $500{ }^{\circ} \mathrm{C}$ with cooling rate of $20{ }^{\circ} \mathrm{C}$ per minute. After the balance calculation in the POLY-3 module, the vertical section phase diagram of the Fe-B pseudo-binary phase diagram is obtained, as shown in Figure 1.

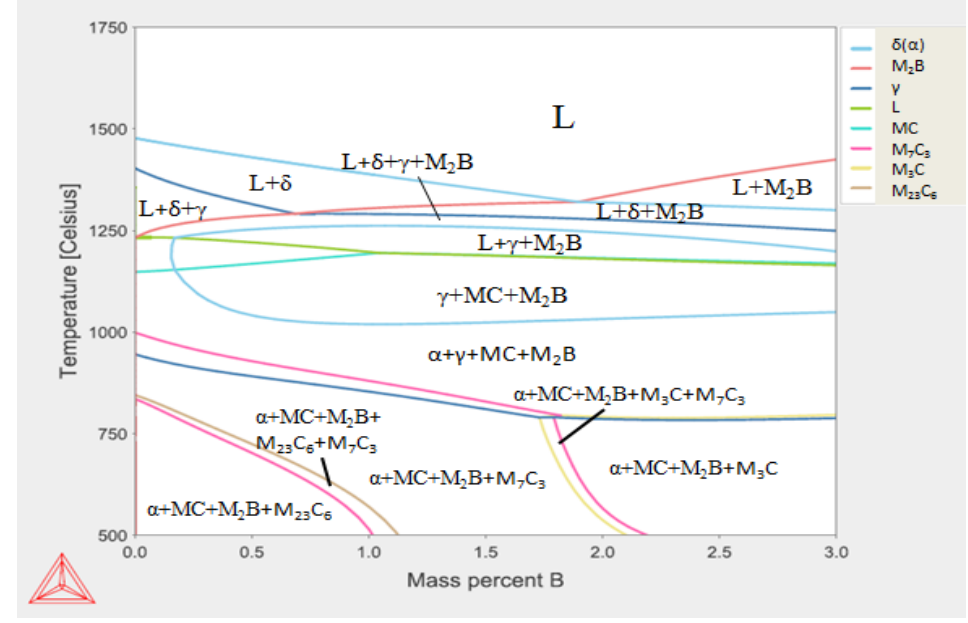

Figure 1: Fe-B equilibrium phase calculated by Thermo-Calc.

\subsubsection{Quenching process}

The accuracy of phase diagram obtained by the Thermo-Calc software has been confirmed in previous work [23]. From the Fe-B equilibrium phase diagram, when the boron content is between 0-3.0\%, the phase transition temperature range is from $1150{ }^{\circ} \mathrm{C}$ to $1220{ }^{\circ} \mathrm{C}$. In order to avoid the specimen over-burnt, the quenching temperature should be controlled under $1100{ }^{\circ} \mathrm{C}$. At the same time, the austenitization can be carried out only when the temperature higher than $800{ }^{\circ} \mathrm{C}$, so the quenching temperature should be higher than $800^{\circ} \mathrm{C}$. Comprehensive consideration, the quenching temperature is $900{ }^{\circ} \mathrm{C}, 950{ }^{\circ} \mathrm{C}, 1000{ }^{\circ} \mathrm{C}, 1050{ }^{\circ} \mathrm{C}$ and $1100{ }^{\circ} \mathrm{C}$. The holding time is 4 hours and the oil cooling method is chosen.

\subsection{Experimental method}

Investigation techniques used for HB-HSS included optical microscopy (OM) and scanning electron microscopy (SEM). The samples were etched with $4 \%$ nital for optical microscopy examination, while a mixture of $5 \mathrm{cc} \mathrm{HCl}, 45 \mathrm{cc} 4 \%$ picral and $50 \mathrm{cc} 5 \%$ nital was used as an etchant for SEM evaluation. The optical microscopy used was an OLYMPUS BX51. The scanning electron microscopy used was a FEI QUANTA200. XRD was performed on the bulk specimens and was carried on a 7000D diffractometer with Copper $\mathrm{K} \alpha$ radiation at $40 \mathrm{kV}$ and $200 \mathrm{~mA}$ as an X-ray source. The sample was scanned in the $2 \theta$ range of $20^{\circ}-80^{\circ}$ in a step-scan mode $\left(0.02^{\circ}\right.$ per step). Macro-hardness measurement of high vanadium wear-resistant alloy was done using an HR-150A type Rockwell hardness tester. The test load was $150 \mathrm{~kg}$. The microhardness of matrix was measured by using a MICRO MET-5103 type Vickers-hardness tester with a load of $1.96 \mathrm{~N}$ and the time of 10s. At least seven indentations were made on each sample under each experimental condition to check reproducibility of the hardness data.

\section{RESULTS}

\subsection{XRD analyses of HB-HSS}

The 1\# samples with as-cast and quenched state were selected for XRD analysis. The XRD curves are shown in Figure 2. From the XRD results, the matrix is $\alpha$ phase in as-cast and quenched state and the hard phases 
are $\mathrm{M}_{2}(\mathrm{~B}, \mathrm{C}), \mathrm{M}_{7}(\mathrm{~B}, \mathrm{C})_{3}$ and a very small amount of $\mathrm{M}_{23}(\mathrm{~B}, \mathrm{C})_{6}$. Compared with the as-cast sample, the $\mathrm{M}_{2}(\mathrm{~B}, \mathrm{C})$ diffraction peak is more intense in the curve of quenched state sample which indicated the amount of $\mathrm{M}_{2}(\mathrm{~B}, \mathrm{C})$ is much more than the as-cast sample. The reason is that the cooling rate of quenched state sample is much quicker and the distribution of $\mathrm{M}_{2}(\mathrm{~B}, \mathrm{C})$ is more concentrated [24-25]. There are about $1 \%$ vanadium in the HB-HSS. The MC-type $(\mathrm{M}=\mathrm{V}, \mathrm{Mo}, \mathrm{Cr})$ carbides which existed in the equilibrium phase diagram could not be found in the XRD results. As we all known, the vanadium is one of the strongest carbide forming elements. During the cooling process, it will be prior to form MC-type carbides. It is easy to verify that the MC-type carbides are mainly composed of VC. For the vanadium content in the HB-HSS is only $1.0 \%$, the amount of MC-type carbides are too little to be detected by the XRD. Moreover, hard phase $\mathrm{M}_{23}(\mathrm{~B}, \mathrm{C})_{6}$ is few and have not been found by XRD.

(a)

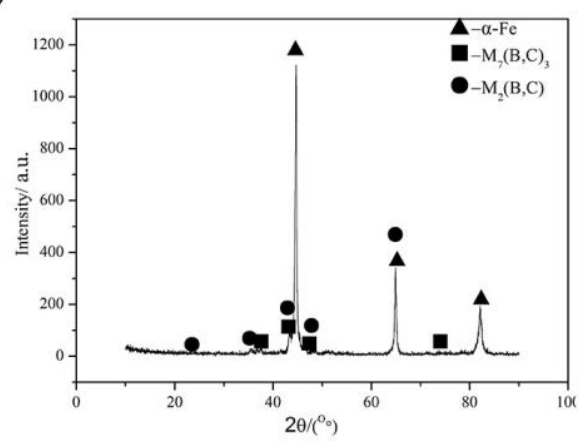

(b)

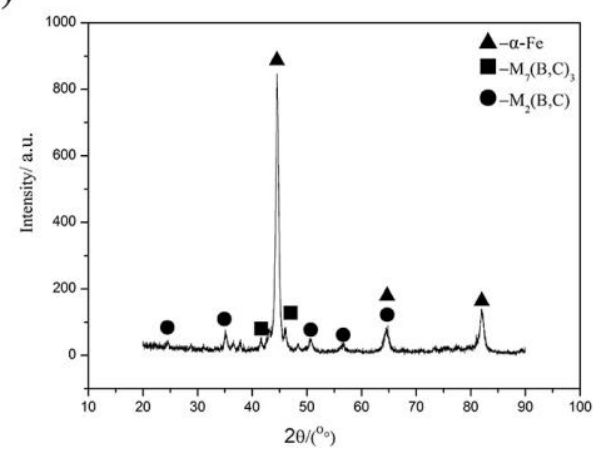

Figure 2: XRD spectrum of as-cast (a) and quenched state (b) of sample 1\# sample.

\subsection{Distribution of alloy element}

In order to study the distribution of the alloy elements in the HB-HSS, the 1\# sample was scanned after $1050^{\circ} \mathrm{C}$ quenching, and the results were shown in Figure 3. From the Figure 3, the Al element is mainly distributed in the matrix, much less in the grain boundary or bulk boron-carbides. Boron and molybdenum segregation is the most serious which are mainly distributed in the grain boundary of borocarbides, but the distribution in the matrix is very little. This distribution feature is favorable to the pinning effect of grain boundary, which can increase the strength of HB-HSS. The distribution of chromium and vanadium in the matrix and the borocarbides is uniform. It is beneficial to improve the hardenability of HB-HSS material. 

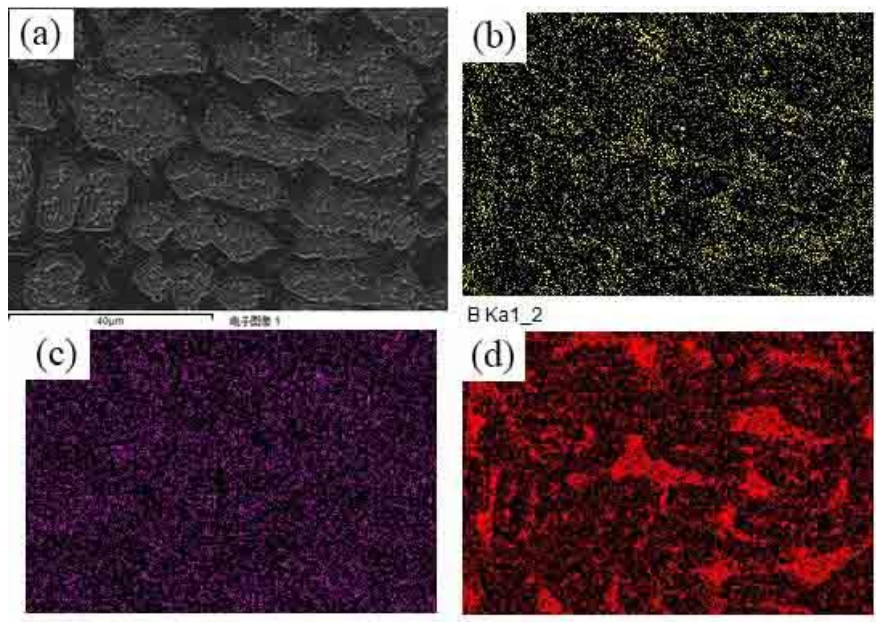

Al Ka1 MoLa1
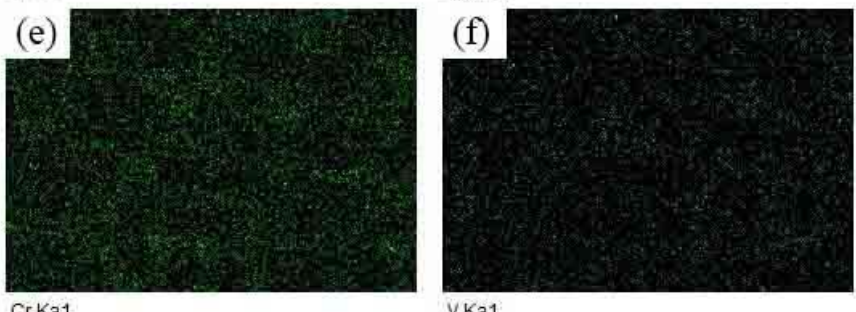

Figure 3: SEM and map scanning images of quenching 1\# sample. (a) SEM; (b-f): element distribution of $\mathrm{B}, \mathrm{Al}, \mathrm{Mo}, \mathrm{Cr}$, and V.

\section{DISCUSSION}

\subsection{Quenched microstructure of 1\# sample after different temperature}

In order to determine the quenching temperature range for each group of samples, the $1 \#$ sample (B 1.0\%, $\mathrm{Al}$ $1.0 \%$ ) was selected for quenching treatment at different temperatures. The heating temperature is $900{ }^{\circ} \mathrm{C}, 950$ ${ }^{\circ} \mathrm{C}, 1000{ }^{\circ} \mathrm{C}, 1050{ }^{\circ} \mathrm{C}$ and $1100{ }^{\circ} \mathrm{C}$ respectively, holding for 4 hours and then cooled by oil. The microstructure and SEM morphology of as-cast and quenched samples at different temperatures are shown in Figures 4 and 5. The test results of the hardness are shown in Figure 6. 

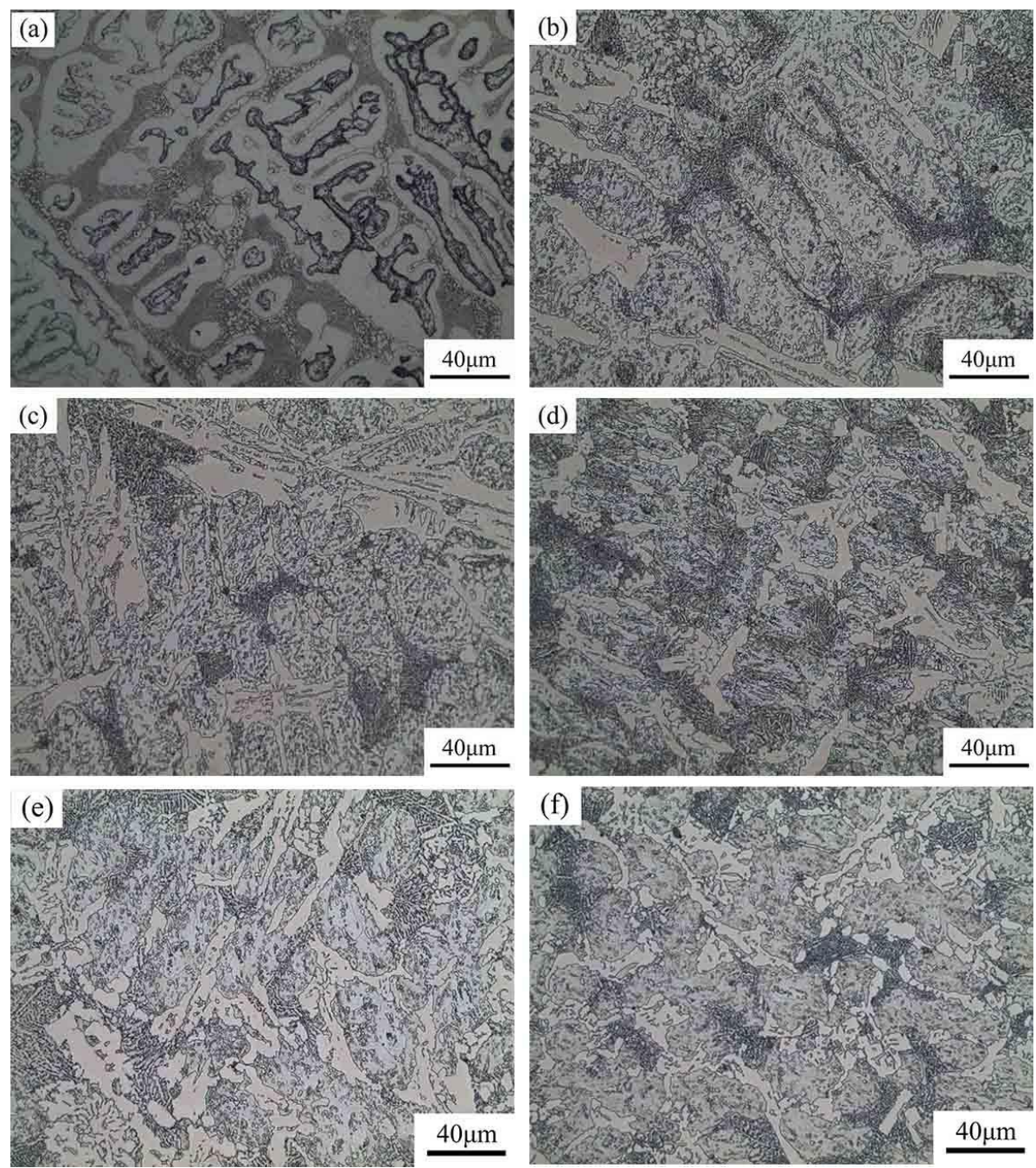

Figure 4: OM pictures of as-cast(a) and quenched at $900{ }^{\circ} \mathrm{C}(\mathrm{b}), 950{ }^{\circ} \mathrm{C}(\mathrm{c}), 1000{ }^{\circ} \mathrm{C}(\mathrm{d}), 1050{ }^{\circ} \mathrm{C}(\mathrm{e})$ and $1100{ }^{\circ} \mathrm{C}(\mathrm{f})$ of $1 \#$ sample.
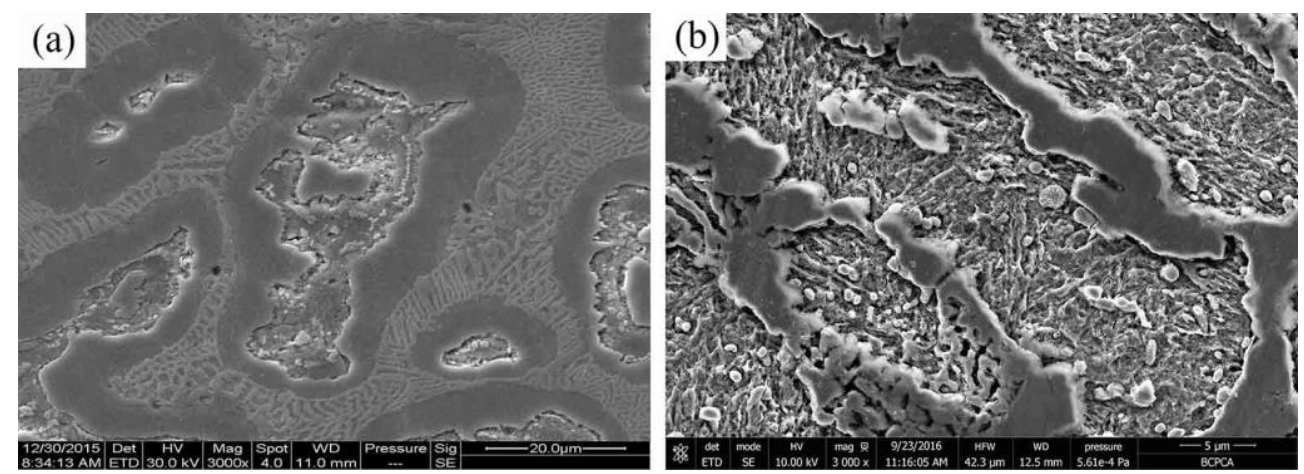

Figure 5: SEM morphology of as-cast (a) and quenched at $1050^{\circ} \mathrm{C}$ (b) $1 \#$ sample. 


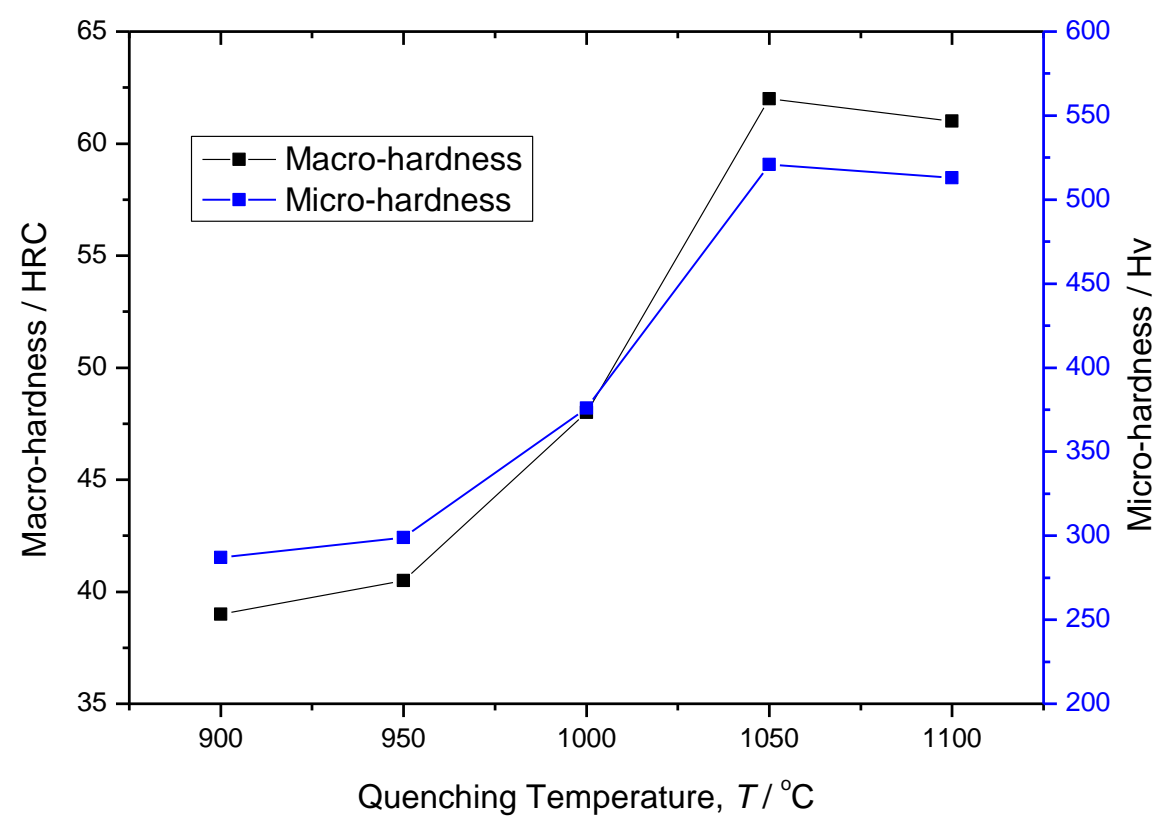

Figure 6: Rockwell hardness of as-cast and quenched of 1\# sample.

The microstructure of as-cast sample is composed with eutectic borocarbides, lath martensite, and pearlite. Matrix is encircled by the eutectic borocarbides and showed as cell-like. Some borocarbides are precipitated along the austenite grain boundary which shown as mesh-like structure. The macro-hardness of as-cast sample is $38.5 \mathrm{HRC}$. Compared with as-cast sample, the microstructure of quenched samples is composed with cryptocrystalline martensite (grey) and borocarbides (white part). With the increasing of quenching temperature, the borocarbides mesh-like structure is partially destructed, and the broken network borocarbide distributed evenly in matrix. At the same time, the size of borocarbide is also refinement with the increase of temperature. It can be known that the quenching temperature is beneficial to the refinement of borocarbide.

The effect of quenching temperature on the macro-hardness and the matrix micro-hardness of HBHSS is shown in Figure 6. When the quenching temperature is lower than $1050{ }^{\circ} \mathrm{C}$, the macro-hardness and the micro-hardness of matrix increase significantly with the increase of quenching temperature. When the quenching temperature exceeds $1050{ }^{\circ} \mathrm{C}$, the macro-hardness and the micro-hardness of matrix have a decrease tendency. The main reason is that the matrix of HB-HSS is mainly composed of ferrite and pearlite that have lower micro-hardness, when the quenching temperature is no more than $1000{ }^{\circ} \mathrm{C}$. This cause that the macro-hardness of HB-HSS is lower. The matrix is transformed from ferrite and perlite to martansite with high micro-hardness after quenching at $1050{ }^{\circ} \mathrm{C}$. At the same time, when HB-HSS is quenched at high temperature and rapid cooling, the diffusion of boron atoms from the intragranular to the grain boundary is prevented, which makes boron dissolve into the matrix to form supersaturated solid solution and lead to larger lattice distortion. Thus, the macro-hardness and the micro-hardness of matrix are both obviously improved while quenching at $1050{ }^{\circ} \mathrm{C}$.

\subsection{Quenched microstructure of 2\# - 5\# samples at $1050{ }^{\circ} \mathrm{C}$}

According to the results of quenching treatment of $1 \#$ sample, the $2 \#-5 \#$ samples were quenched at $1050{ }^{\circ} \mathrm{C}$, holding for 4 hours and cooled by oil as 1\# sample. The microstructure is shown in Figure 7 and macrohardness test results are shown in Figure 8. From the as-cast sample (sample 1\#-3\#), the microstructure of alloy is composed with eutectic borocarbides and lath martensite and pearlite. With the increasing of boron content, the amount of borocarbides increased significantly, and the morphology of borocarbides changes from mesh-like structure (the sample $1 \#$ with $1.0 \% \mathrm{~B}$ ) to fishbone and block structure (the sample $2 \#$ with $2.0 \% \mathrm{~B}$ ). When the content of $\mathrm{B}$ increases to $3.0 \%$, the morphology showed as block and chrysanthemum rosette (the sample $3 \#$ with $3.0 \% \mathrm{~B}$ ). Compared with as-cast sample, the microstructure of quenched sample (sample 1\#-3\#) is composed with cryptocrystalline martensite (grey) and borocarbides (white part). The quenched structure of borocarbides has been destructed partly and a small amount of fine borocarbides precipitated in the matrix, which can enhance the macro-hardness of HB-HSS. 

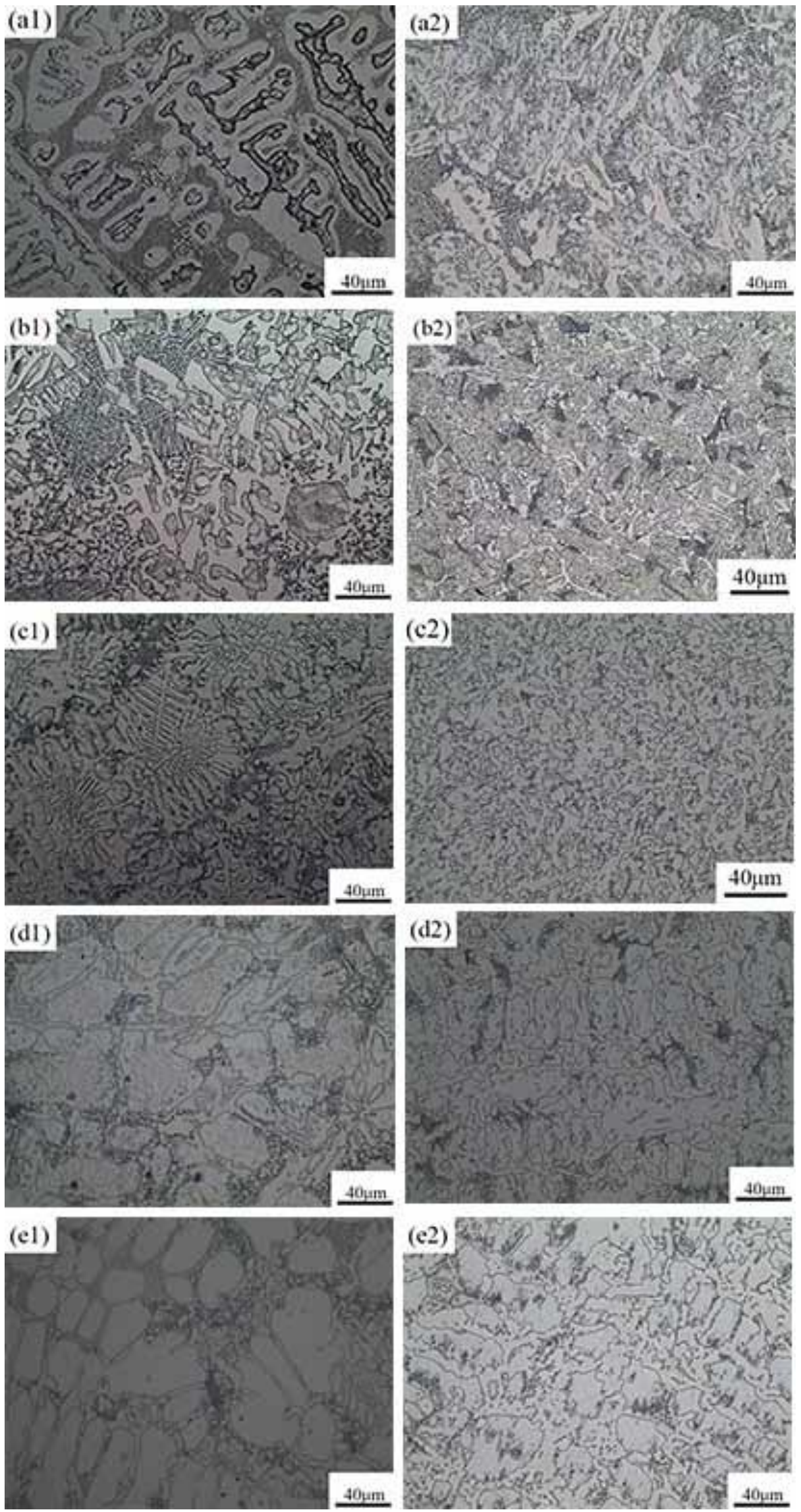

Figure 7: $\mathrm{OM}$ pictures of as-cast (a1-e1) and quenched at $1050{ }^{\circ} \mathrm{C}(\mathrm{a} 2-\mathrm{e} 2)$ of $1 \#-5 \#$ specimens (letters a, b, c, d, and e correspond to 1\#, 2\#, 3\#, 4\#, and 5\# specimens, respectively). 


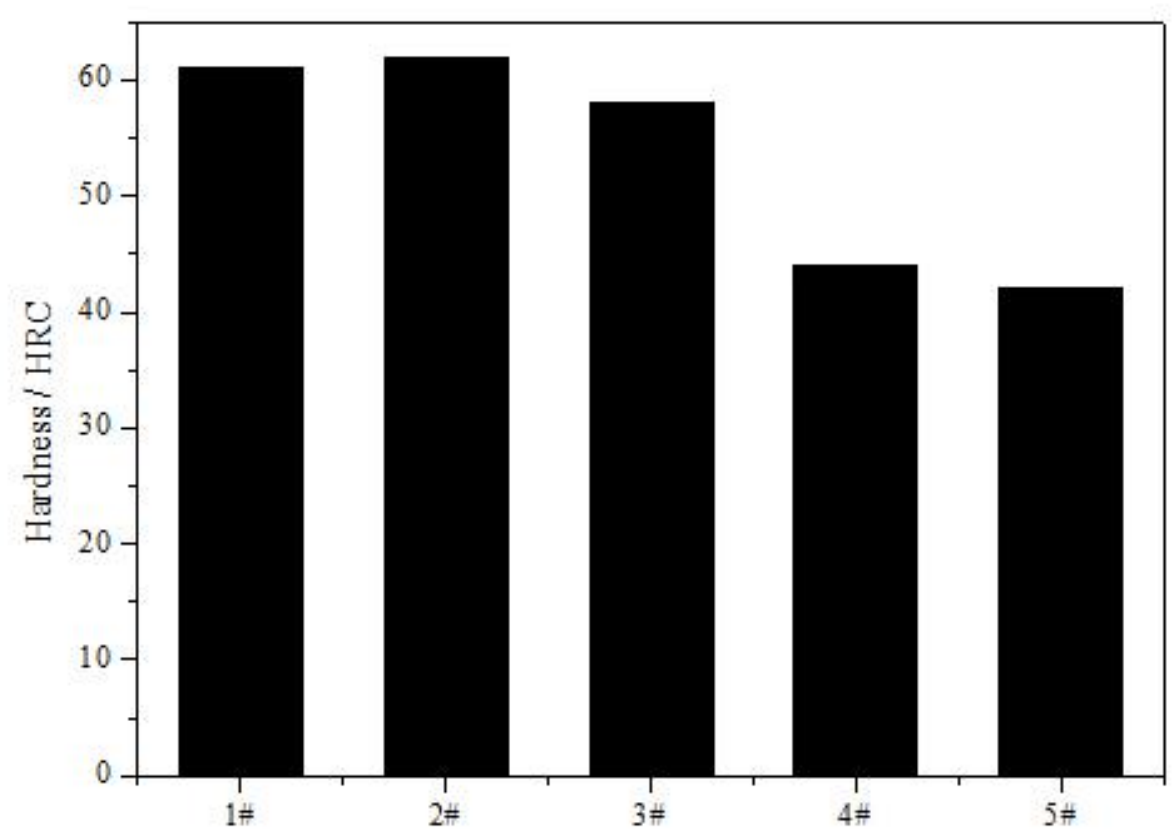

Figure 8: Rockwell hardness of $1 \#-5 \#$ sample after quenching at $1050{ }^{\circ} \mathrm{C}$.

The boron contents of $2 \#, 4 \#$ and $5 \#$ sample are $1.82 \%, 1.78 \%$ and $1.84 \%$ respectively, while the aluminum contents are $0.80 \%, 1.24 \%$ and $2.08 \%$ respectively. Compared with $2 \#$ sample, it can be known that the 4\# sample has a small amount of bulk ferrite in the matrix. The hard phase is still eutectic borocarbides, but the thickness of the borocarbides is obviously thinner, especially the appearance of ferrite, which makes the mesh-like structure tend to shrink. The matrix microstructure of 5\# sample has been transformed into pearlite. The hard phase is borocarbides but the mesh-like structure has been destructed partly and the residual mesh-like structure appears a large number of micro-cellular, for the increase of aluminum obstacles the formation of eutectic borocarbides. Due to the increase of ferrite, the austenite process cannot be carried out completely during the quenching process. A large number of ferrite still exists in matrix after quenching, which results the macro-hardness is lower than $2 \#$ sample. The quenching hardness of $4 \#$ samples 5\# is $44 \mathrm{HRC}$ and $42 \mathrm{HRC}$ respectively. According to the microstructure and hardness analysis, when the quenching temperature is $1050{ }^{\circ} \mathrm{C}$ and the aluminum content is $1.0 \%$, the boron content of 1.0-2.0\%, HB-HSS can be obtained with high hardness and good toughness. On this basis, the microstructure and hardness under different tempering temperatures can be further studied in the future.

\section{CONCLUSIONS}

1) As-cast microstructures of HB-HSS containing $0.4 \% \mathrm{C}-6.0 \% \mathrm{Cr}-4.0 \% \mathrm{Mo}-1.0 \% \mathrm{~V}-1.0 \% \mathrm{Si}-0.5 \mathrm{Mn}-\mathrm{x} \% \mathrm{~B}-$ $\mathrm{y} \% \mathrm{Al}(\mathrm{x}=1.0,1.5,2.0, \mathrm{y}=1.0,2.0,3.0)$ consist of the metallic matrix and eutectic borocarbides, and the metallic matrix is the mixture of martensite and pearlite. When the aluminum content is lower than $1.0 \%$, the morphology of eutectic borocarbides changed from mesh-structure to block and chrysanthemum rosette with the increase of boron content from $1.0 \%$ to $3.0 \%$.

2) When the boron content is $2.0 \%$, and the aluminum content is more than $1 \%$, aluminum will lead to the increase of ferrite in the matrix, which makes the hardness of HB-HSS decrease significantly.

3) When the aluminum content is $1.0 \%$ and the boron content is in the range of $1.0-2.0 \%$, HB-HSS can obtain high hardness quenching at $1050{ }^{\circ} \mathrm{C}$.

\section{ACKNOWLEDGEMENTS}

This work was supported by 100 Talents Project of Shaanxi province. 


\section{BIBLIOGRAPHY}

[1] KANG, M., LEE, Y.K., "The effects of austenitizing conditions on the microstructure and wear resistance of a centrifugally cast high-speed steel roll”, Metallurgical and Materials Transactions A, v. 47, n. 7, pp. 3365-3374, Jul. 2016.

[2] FU, H.G., ZHAO, H.J., DU, Z.Z., et al., "Heat treatment of centrifugally cast high carbon high vanadium high speed steel mill roll”, Ironmaking and Steelmaking, v. 38, n. 5, pp. 338-345, Jul. 2011.

[3] HA, D.J., SUNG, H.K., PARK, J.W., et al., "Effects of alloying elements on microstructure, hardness, wear resistance, and surface roughness of centrifugally cast high-speed steel rolls", Metallurgical and Materials Transactions A, v. 40, n. 11, pp. 2568-2577, Nov. 2009.

[4] RÖTTGER, A., WEBER, S., THEISEN, W., "Supersolidus liquid-phase sintering of ultrahigh-boron high-carbon steels for wear-protection applications", Materials Science and Engineering A, V. 532, n. 1, pp. 511-521, Jan. 2012.

[5] MA, S.D., ZHANG, J.J., "Wear resistant high boron cast alloy - A review", Reviews on Advanced Materials Science, v. 44, n. 1, pp. 54-62, Jan. 2016.

[6] YI, Y.L., XING, J.D., WAN, M.J., et al., "Effect of $\mathrm{Cu}$ on microstructure, crystallography and mechanical properties in Fe-B-C-Cu alloys", Materials Science and Engineering A, v 708, n. 1, pp. 274-284, Dec. 2017.

[7] XU, L.J., ZHANG, G.S., LI, J.W., et al., "Research on microstructure and mechanical properties of high boron cast steel”, Advanced Materials Research, v. 189-193, pp. 3968-3971, Apr. 2011.

[8] MA, Y., LIU, Y., LI, J., et al., "Effect of isothermal quenching methods on impact toughness and wear resistance in high boron steel", International Journal of Materials Research, v. 106, n. 2, pp. 151-159, Feb. 2015.

[9] FU, H.G., MA, S.Q., HOU, J.Q., et al., "Microstructure and properties of cast B-bearing high speed steel”, Journal of Materials Engineering and Performance, v. 22, n. 4, pp. 1194-1200, Apr. 2013.

[10] JIANG, Y., CEN, Q.H., JIANG, Y.H., et al., "Effect of cooling rate on microstructure of high boron high speed steel roll ring produced by centrifugal casting", Transactions of Materials and Heat Treatment, $\mathrm{v}$. 34, n. 4, pp. 128-132, Apr. 2013.

[11] HOU, J.Q., FU, H.G., LEI, Y.P., et al., "Microstructure of as-cast low alloy high speed steel roll containing boron”, Transactions of Materials and Heat Treatment, v. 32, n. 7, pp. 100-103, Jul. 2011.

[12] XU Z.Y., "Effect of aluminum in the high speed steel”, Mechanical Engineering Materials, v. 17, n. 2, pp. 4-5, Apr. 1993.

[13] CHI, H.X., MA, D.S., YOHG, Q.L., et al., "Effect of aluminum on critical point and quenched microstructure of Cr8WMo2V2SiNb steel”, Transactions of Materials and Heat Treatment, v. 30. n. 6, pp. 61-68, Jun. 2009.

[14] ZHOU, X.F., YIN, X.F., FANG, F., et al., "Study on the solidification microstructure of aluminum alloyed high speed steel”, Advanced Materials Research, v. 217-218, pp. 463-467, Aug. 2011.

[15] MA, S.Q., XING, J.D., GUO, S.Q. et al., "Microstructural evolution and mechanical properties of the aluminum-alloyed Fe-1.50 wt\%B-0.40 wt\%C high-speed steel”, Materials Chemistry and Physics, v. 199, pp. 356-369, Sep. 2017.

[16] MA, S.Q., XING, J.D., HE, Y.L. et al., "Effect of heat treatment on microstructures and mechanical properties of al-modified boron high speed steel”, Key Engineering Materials, v. 732 pp. 24-31, Feb. 2017.

[17] BAO, Y.L., CEN, Q.H., JIANG, Y.H., et al., "Effect of quenching temperature on microstructure of high-boron high speed steel", Transactions of Materials and Heat Treatment, v. 33, n. 7, pp. 72-75, Jul. 2012.

[18] SU, H., YANG, C.F., CAI, F., et al., The application of thermodynamics and kinetics calculation technology in the iron and steel research, Beijing: Science Press, 2012.

[19] SUNDMAN, B., JANSSON, B., ANDERSSON, J.O., "The Thermo-Calc databank system", Calphad: Computer Coupling of Phase Diagrams and Thermochemistry. v. 9, n. 2, pp. 153-190, Feb. 1985.

[20] QIAO, Z.Y., HAO, S.M., "New progress of CALPHAD approach”, Journal of Material and Metallurgy, v. 4, n. 2, pp. 84-89, Feb. 2005.

[21] KAUFMAN, L., AGREN, J., "CALPHAD, first and second generation - Birth of the materials genome, Scripta Materialia, v. 70, n. 1, pp. 3-6, Jan. 2014. 
[22] YANG, Y.W., FU, H.G., LEI, Y.P., et al., "Phase diagram calculation and analyze on cast high boron high-speed steel", Journal of Materials Engineering and Performance, v. 25, n. 3. pp. 409-420, Mar. 2016.

[23] YANG, Y.W., FU, H.G., WANG, K.M., et al., "Effect of aluminum on the phase diagram and solidification microstructure of high boron high speed steel", Transactions of Materials and Heat Treatment, v. 36, n. 7, pp. 48-54, Jul. 2016.

[24] LUAN, Y.K., SONG, N.N., BAI, Y.L. et al., "Effect of solidification rate on the morphology and distribution of eutectic carbides in centrifugal casting high-speed steel rolls", Journal of Materials Processing Technology, v. 210, n. 3, pp. 536-541, Feb. 2010.

[25] SONG, X.D., FU, H.G., YANG, J., "Effect of heat treatment on microstructure and properties of wear resistant cast Fe-C-B alloy", Transactions of Materials and Heat Treatment, v. 29, n. 1, pp. 38-41, Jan. 2008.

\section{ORCID}

Fu Han-guang

Yang Yong-wei

Qu Yin-hu

Cheng Xiao-le https://orcid.org/0000-0003-2572-7938

https://orcid.org/0000-0003-4905-3755

https://orcid.org/0000-0002-8294-6099

https://orcid.org/0000-0002-5415-7893 